\title{
STUDY OF PUBLIC SERVICE IMPLEMENTATION IN SOME LOCAL GOVERNMENT ORGANIZATIONS OF CENTRAL JAVA PROVINCE IN 2021
}

\author{
By \\ Sodikin
}

BPSDMD Provinsi Jawa Tengah

Email : sodikinwidyaiswara@gmail.com

\begin{tabular}{l}
\hline \hline Article Info \\
\hline Article history: \\
Received May 19, 2021 \\
Revised June 26, 2021 \\
Accepted July 21, 2021
\end{tabular}

Keywords:

Public Service

Public Service Constraints

Solutions

\begin{abstract}
Public service is an activity or series of activities in the context of fulfilling basic needs in accordance with the civil rights of every citizen and resident of goods, services, and or administrative services provided by public service providers. The government as a public service provider is required to carry out the best service / excellent service so that the public as service users feel satisfied. The Central Java Provincial Government as a public service provider in the Central Java Province has tried to comply with the provisions of Law Number 25 of 2009 concerning Public Services, as well as in the Regulation of the Minister of Empowerment of State Apparatus and Bureaucratic Reform Number 15 of 2014 concerning Guidelines for Service Standards. Service standards at least contain: legal basis, requirements, service procedures, completion time, service costs, service products, facilities and infrastructure, competence of service providers, internal control, complaint handling, suggestions and inputs and service guarantees. However, efforts to improve public services still face several obstacles. These constraints include human resources for implementing services, inadequate service facilities and budget refocusing, causing delays in the completion of public service facilities. However, the regional apparatus organizations or technical implementing units for public service providers have been trying to come up with solutions. However, Central Java Provincial Government policies are still needed to improve the quality of services gradually.
\end{abstract}

This is an open access article under the CC BY-SA license.

Corresponding Author:

\section{Sodikin}

BPSDMD Provinsi Jawa Tengah

Email : sodikinwidyaiswara @ gmail.com

\section{INTRODUCTION}

The implementation of public services is the state's obligation in order to fulfill the basic rights of citizens which have been guaranteed in the 1945 Constitution. For the implementation of these public services, the government has established technical institutions both at the central and regional levels as providers of public services. Likewise, a legal regulation has also been made, namely Law Number 25 of 2009 concerning Public Services. The law also mandates the existence of service standards, service information systems, complaints systems and complaints services, service dispute resolution and supervision of the implementation of public services carried out by the ombudsman committee.

Following up on the government's policy on public services, the Central Java provincial government has issued Regional Regulation Number 7 of 2015 concerning Public Services. These regulations become the legal basis for the implementation of public services within the Central Java Provincial Government. In the implementation of public 
services, human resources of service providers are a very determining factor for service quality. In addition, the availability of the necessary facilities or equipment. The more complete the facilities, the easier it is for public services to be implemented.

\section{RESEARCH METHOD}

This study aims to determine the implementation of excellent service carried out by several Regional Apparatus Organizations of Central Java Province. This study uses a qualitative descriptive method, which is a research method that utilizes qualitative data and is described descriptively.

Collecting data using in-depth interview techniques to the implementers of public services in each of the Regional Apparatus Organizations of Central Java Province.

\section{RESULTS AND ANALYSIS}

\section{a. Excellent Service at the Turusgede Elderly Social Service Home}

The Turusgede Elderly Social Service Orphanage in Turusgede Village, Rembang District, Kembang Regency is a Technical Service Unit of the Social Service of Central Java Province. In June 2021, there were 145 residents of the orphanage who had unstable health conditions, with 29 employees. Thus, the ratio of the number of employees to the elderly in this orphanage is $1: 5$, meaning that each employee must serve 5 elderly people. These seniors must be supervised 24 hours a day to avoid offenses such as fighting among the elderly, theft and escape. Before being accepted as residents of the orphanage, the elderly must undergo health care. However, there are many elderly who come in sick, it is the nursing home who then check with health services. After recovering, the elderly are often referred to an orphanage that is more in line with their health conditions.

The main cause of the problems that occur is the lack of Human Resources as service providers. In addition, there are no health workers, psychologists, psychiatrists, so the institution has to pay money to bring in these experts to help provide services.

The alternative solutions that can be implemented are :

1. Make a supervision picket schedule

2. Continue to cooperate with external parties for health services

b. Excellent Service in the work unit of SMK Negeri 1 Kebumen

Some of the problems in providing excellent service at SMK 1 Kebumen are:

1. Security guard posts are still limited,

2. The parking lot for student vehicles is still not spacious and inadequate,

3. Limited administrative space. Some rooms are still one function with other activities

The causes of this problem are:

1. There are two security personnel, preferably two posts

Care for maximum security.

2. The student parking space is inadequate, so there are many motorbikes

students parked not in the parking lot.

3. Related to the interests of students in taking care of administrative matters

sometimes This creates a lot of queues and less orderly.

4. There are several rooms that are used together, for example extra room theater

and music room. This results in services are hampered and less than optimal.

Possible alternative solutions to be implemented are:

1. Build a Security Post at the exit;

2. Build a special parkie for teachers, technical personnel and students;

3. Building a wider administrative space so that administrative services for students run smoothly;

4. Build a larger extra-curricular space so that students can channel their hobbies.

\section{c. Excellent Service at the Medical Record Unit of Kelet Hospital, Central Java}

\section{Province}

The medical record unit at the Kelet Hospital, Central Java Province is one of the supports that serve patients directly, through patient registration services. Outpatient registration, emergency patient registration and inpatient registration. In addition to providing convenience to patients, such as online registration services, easy registration requirements, problems related to excellent service are still found, including:

1) There is no special uniform for registration officers.

The registration officer only follows the uniform provisions of the Kelet Hospital, for example Monday PDH kheki, Tuesday the striated uniform. In addition, awareness of officers wearing attributes such as name, corporal pin and Id 
International Journal of Social Science (IJSS)

Vol.1 No.2 August 2021, pp: 115-120

ISSN: 2798-3463 (Printed) | 2798-4079 (Online)

DOI: https://doi.org/10.53625/ijss.v1i2.144

Card, employee uniforms that have been provided from RSUD Kelet are still lacking. This gives the impression of being incompatible.

2) Application of $5 \mathrm{~S}$ (smiles, greetings, greetings, courtesy and manners) by registration officers in providing services to patients.

The provision of $5 \mathrm{~S}$ (smiles, greetings, greetings, courtesy and manners) has not been all done by the registration officer. Including setting the tone of the registration officer's speech which sometimes seems fierce or impolite. In addition, there are services that prioritize and accept family or relatives or friends registration deposits.

3) The procedure for the patient to arrive late when the queue number has been called is not clear.

Lack of information if the patient arrives late when the queue number has been called for outpatient registration so that it seems less respect for patients. If the patient is late, the patient will be served after the next three patient services. For old patients, they usually go straight to the registration counter, and wait three times for services. However, new patients or never too late feel discriminated against.

4) Lack of information.

There are no television facilities in the entire waiting room for the registration of RSUD Kelet. In addition, there is no display of information on the availability of beds and the latest bed facilities for inpatient registration.

After a simple analysis of the problem, the causes were found, namely:

1. There is no reprimand from the leadership or employee discipline enforcers regarding uniforms and attributes of registration officers.

2. There are no rules or SOPs in providing services with $5 \mathrm{~S}$ (smiles, greetings, greetings, courtesy, and manners).

3. Has never been given excellent service training to all registration officers.

4. Lack of patient education facilities if they arrive late when they are called.

5. There are no facilities to provide education to patients, monitor screens or television.

The alternative solutions that can be implemented are:

1. RSUD Kelet provides special uniforms for registration officers so that officers look harmonious and more polite.

2. Forming a team of employee discipline enforcement in charge of monitoring and evaluating the service and neatness of officers.

3. Formulate clearer regulations and SOPs related to excellent service, such as the obligation to provide $5 \mathrm{~S}$ to every patient, prohibition of accepting registration deposits.

4. Provide excellent service training to the registration officer of the Kelet Hospital.

5. Provide patient access to provide service assessment (Customer Satisfaction Assessment) from each registration officer after completion of service.

6. Giving rewards to the registrar for the patient's assessment.

7. Provide announcements that are easily accessible to patients regarding regulations for late arrival of patients or the existence of other new regulations so that patients feel more respected or valued.

8. Provide more complete facilities and infrastructure to patients so that patient comfort is maintained.

d. Excellent Service at the Department of Public Works of Highways and Human Settlements of Central Java Province in the Field of Implementing Roads for the East Region follows:

The problems that exist in the Eastern Region Road Implementation Sector related to Excellent Service are as

1. At the beginning of the Corona Virus-19 pandemic, there were cuts / adjustments / refocusing of the budget which required an adjustment to the value of the work contract so that the long target for handling road improvements could not be achieved.

2. The Corona Virus-19 pandemic also has an impact on the bridge construction/duplication work package which is planned to be completed in one fiscal year to become more than one budget year, resulting in delays in the people in the regions enjoying the results of the bridge construction/duplication.

3. The implementation of the Work From Home system is felt to hamper communication and coordination between employees. 
4. The general public is not aware of the existence of a program to use labor to improve roads and bridges taken from community groups around the road section of the East Region Road Implementing Division.

Analysis of the causes of problems that occur in the Eastern Region Road Implementation Sector are as follows:

1. The Corona Virus-19 pandemic requires the Regional Government to allocate a large portion of the APBD to the health and social sector as a top priority.

2. The occurrence of restrictions on community activities or large-scale social restrictions on roads which are the area of the Eastern Region Road Implementation Sector, causing some of the workers used to be unable to work optimally.

3. In the event that there is an urgent problem that requires an immediate solution, it is not uncommon to have problems with employees who are WFH when they should attend the relevant meeting.

4. There is no delivery of information to the public regarding the utilization of road and bridge improvement workers who use personnel from community groups around the road section of the Eastern Region Road Implementation Division.

The solutions to various problems in the Eastern Region Road Implementation Sector are as follows:

1. The long target for handling the delayed road improvement should be budgeted for in the next fiscal year to meet the complete handling of the toll road in Central Java.

2. Delayed bridge construction/duplication can also be re-budgeted in the next fiscal year so that it can be completely completed and enjoyed by the community.

3. Addition of employees who have shifts to work in the office/field, and only $30 \%$ or less employees who are WFH.

4. The use of the Cinta Field application which can be accessed by the general public through the website of the Public Works Department of Highways and Human Settlements of Central Java Province where this application contains all kinds of road and bridge improvement activities that are being carried out by the Provincial Public Works Department of Highways and Human Settlements. Central Java.

\section{e. Excellent Service at Work Safety Center - Department of Manpower and}

\section{Transmigration of Central Java Province}

Based on Central Java Governor Regulation Number 52 of 2018 concerning the Organization and Work Procedure of Regional Technical Implementation Units at the Manpower and Transmigration Office of Central Java Province it is stated that the Class A Work Safety Center has the task of carrying out operational technical tasks and/or certain supporting technical activities of the Office in the Field work safety, health, and ergonomics.

In accordance with the Decree of the Head of the Central Java Province Work Safety Center Number 1910/2019 concerning Public Service Standards in the Central Java Province Work Safety Center, it states that the types of services within the Central Java Provincial Work Safety Center include:

1. Work Environment testing service

2. Air Quality Testing Service

3. Health check services for workers

4. Occupational Safety Hyperkes Training Services

5. OHS Competency Test Service

6. K3 Clinic Services

In implementing the service function, the Occupational Safety Center has policies, service announcements, quality targets, Public Service Standard Decrees, Service SOPs and evaluates services using the online community satisfaction survey application eskm.jatengprov.go.id/skm/419. Based on the 2019 community satisfaction survey, the Work Safety Center has a good assessment result.

Training services at the Occupational Safety Center during the Covid-19 pandemic are carried out online with the zoom platform and forms that must be filled out by participants also using online media, such as: google forms and zoho forms.

Some of the shortcomings in excellent service at the Work Safety Center, including:

1. Digitization of training services creates difficulties for participants who are not accustomed to using online media.

2. The training carried out using online media is highly dependent on the internet network.

3. Delayed environmental testing schedule.

The causes of this problem are

1. The training participants consist of various groups from young to old so that not all participants are familiar with online-based applications. 
International Journal of Social Science (IJSS)

Vol.1 No.2 August 2021, pp: 115-120

ISSN: 2798-3463 (Printed) | 2798-4079 (Online)

DOI: https://doi.org/10.53625/ijss.v1i2.144

2. The training consists of organizers, resource persons and participants who are interrelated for the continuity of effective training. Internet interference on one side causes the implementation of the training to be less than optimal.

3. The Covid-19 pandemic has caused the work environment testing activity schedule that has been prepared to be postponed or canceled because the testing location is in the red zone or the company must require rapid or swab tests while the agency does not have a budget for rapid or swab tests.

The solutions to overcome the shortcomings in this excellent service are:

1. Make a short tutorial or FAQ (a list of frequently asked questions) about the online media used in the training so that participants better understand the implementation of this online training.

2. The training organizer provides an understanding to the resource persons and participants about the importance of the internet network, so that all parties involved in the training have the same awareness to create an effective training.

3. Training organizers make better preparations for training by conducting $\mathrm{H}-1$ training simulations for the implementation of the training, as well as testing the internet network so that the training runs smoothly.

4. Coordinate with companies where environmental testing will be carried out to schedule retesting after the situation is better (not a red zone).

\section{f. The Problem of Excellent Service at SMA Negeri 4 Pekalongan}

The types of services at SMA Negeri 4 Pekalongan consist of 6 types of services: Curriculum Services, Student Services, Facilities and Infrastructure Services, Public Relations Services, Guest Reception Services, and Administrative Services. From some of these types of services there are deficiencies that cause the service to be less good and less satisfying. Some of the obstacles to the service in question are the lack of human resources, supporting facilities to maximize services and the lack of communication between service providers and recipients.

Analysis of the causes of the barriers to excellent service are:

a. The schedule is drawn up close to the day of the activity, so that the implementation of the activity is less than optimal.

b. Students who are not actively participating in online learning,

c. Procurement of learning facilities cannot be realized quickly.

d. Lack of communication between the school and several parties.

e. The appointment of daily picket teachers pays less attention to the density of the teacher's teaching schedule so that the picket teachers are less focused on carrying out their duties as receptionists.

f. Lack of Administration in conveying personnel information and other administrative work.

The possible solutions are:

a. Make careful planning at the beginning of the school year.

b. Carry out coordination with homeroom teachers, BK teachers and parents of students through communication media or directly.

c. Plan the needs of each section in detail at the time of budgeting.

d. Actively communicate with interested parties with the school.

e. The picket teacher scheduler coordinates with the curriculum so that the picket teacher schedule can be adjusted to the teacher's teaching schedule

f. Proactive administration seeks the latest information on staffing for related parties and divides tasks according to the number of human resources in the administration so that work can be completed more quickly.

\section{CONCLUSION}

The Central Java Provincial Government in an effort to meet the basic needs of its citizens has organized public services in various sectors, including the education, health, administrative, social and physical development sectors. There are still many obstacles in the implementation of public services. One of these obstacles is the Human Resources of service providers. In some Technical Implementation Units, it is still found that the number of public service implementers is still less than the customers who must be served. Besides, mastery of duties and functions as well as friendliness in carrying out services also still needs to be improved.

Another obstacle is the lack of a place for service delivery, causing customer discomfort. As for the budget, with the refocusing of the budget, public facilities that should be completed within 1 year, need several years to complete. Every Regional Apparatus Organization or Technical Implementation Unit within the Central Java Provincial Government has tried to overcome these public service constraints. However, government policies are still needed so that public services within the Central Java Provincial Government can increase gradually. 


\section{REFERENCES}

[1] Law no. 25 of 2009 concerning Public Services;

[2] Regulation of the Minister for Empowerment of State Apparatus and Bureaucratic Reform Number 15 of 2014 concerning Guidelines for Service Standards;

[3] Regulation of the Minister of State Apparatus Empowerment and Bureaucratic Reform Number 16 of 2014 concerning Guidelines for Community Satisfaction Surveys;

[4] Central Java Provincial Regulation Number 7 of 2015 concerning Public Services;

[5] Regulation of the Minister for Empowerment of State Apparatus and Bureaucratic Reform Number: 24 of 2014 concerning Guidelines for National Public Service Complaint Management 